\title{
PROTEIN, AMINO ACID AND GLUTEN CONTENT IN OAT (Avena sativa L.) GROWN IN LATVIA
}

\author{
Laila Vilmane ${ }^{1,2 \#}$, Sanita Zute ${ }^{1}$, Evita Straumite ${ }^{2}$, and Ruta Galoburda ${ }^{2}$ \\ 1 State Stende Cereal Breeding Institute, „Dižzemes”, Dižstende, Lībagi Civil Parish, Talsi County, LV-3258, LATVIA; \\ lailaozola@inbox.lv \\ 2 Faculty of Food Technology, Latvia University of Agriculture, Jelgava, LV-3001, LATVIA \\ \# Corresponding author
}

Communicated by Daina Kārkliṇa

\begin{abstract}
The rising attention globally on the use of oats and the beneficial effect of oat compounds in nutrition has also increased interest in oat production in Latvia. The aim of this study was to evaluate protein, amino acid and gluten content in husked and hulless oat grains grown in organic and conventional farming systems. Two hulless oat (Avena sativa L.) genotypes - the breeding line '33793' and the variety 'Stendes Emilija' and one husked oat variety 'Lizete' from the State Stende Cereal Breeding Institute - were cultivated in 2013 under conventional farming methods using three nitrogen $(N)$ application rates $\left(80,120\right.$, and $\left.160 \mathrm{~kg} \cdot \mathrm{ha}^{-1}\right)$ and under organic farming. Protein content was determined by Kjeldahl method, amino acid composition by high-performance liquid chromatography method using Waters AccQ Tag, and gluten content by Sandwich R5 ELISA. The results showed that oat genotype had significant effect $\mathrm{p}<0.001)$ on protein and gluten content, as well as on amino acid composition. The applied amount of fertiliser did not have significant effect on the studied quality parameters, but the growing system did $(\mathrm{p}<0.001)$. Higher content of protein was observed in hulless oat samples, compared to that in husked oat samples. There was also a significant difference $(\mathrm{p}=0.01)$ in the total amount of amino acids between husked and hulless oat samples. In hulless oat variety 'Stendes Emilija' and hulless breeding line '33793' the content of gluten was similar and two times higher than in the husked oat variety 'Lizete'. Further breeding work is necessary to obtain oats with a lower content of gluten-like proteins.
\end{abstract}

Key words: oat, protein, amino acid, gluten, farming systems.

\section{INTRODUCTION}

Permanent intolerance to the gliadin fraction of wheat protein and related alcohol-soluble proteins (prolamins) found in rye and barley is defined as coeliac disease. The disorder occurs in genetically susceptible individuals who ingest these proteins, leading to an autoimmune enteropathy that self-perpetuates as long as these food products remain in the diet (Pietzak and Fasano, 2005). Coeliac disease affects approximately $1 \%$ of the general population (Niewinski, 2008); there are approximately 7000 patients in Latvia. The only treatment for coeliac disease is lifelong adherence to a gluten-free diet (Di Sabatino and Corazza, 2009).

According to EU commission regulation No. 41/2009, 'gluten' is a protein fraction from wheat, rye, barley, oats or their crossbred varieties and derivatives thereof, to which some persons are intolerant and which is insoluble in water and $0.5 \mathrm{M}$ sodium chloride solution. Most but not all people with intolerance to gluten can include oats in their diet without adverse effect on their health. This is an issue of ongo- ing study and investigation by the scientific community (Anonymous, 2009). The term 'gluten-free' does not refer to the total absence of gluten. The residual amount of gluten allowed in gluten-free products is strictly regulated by the Codex Alimentarius Standard (Anonymous, 2015). The EU Commission Regulation No. 41/2009 recommends that products not exceeding $20 \mathrm{mg} \cdot \mathrm{kg}^{-1}$ of gluten should be considered gluten-free; a product can be labelled as "very low gluten' and be included in gluten-free diet, if gluten content does not exceed $100 \mathrm{mg} \cdot \mathrm{kg}^{-1}$. Gluten, found in the endosperm of cereals, is composed of distinct portions of monomeric, alcohol-soluble gliadins and polymeric, prolamine-rich glutenins, which are responsible for flour processing characteristics (good water absorption capacity, cohesiveness, viscosity and elastic properties) in the bakery industry (Heap and van Heel, 2009; Arendt and Nunes, 2010; Torbica et al., 2010).

Recently there has been much research and discussions on whether oat can be tolerated in the gluten-free diet or not. Heap and van Heel (2009) included oats in the restricted 
product list, but Mustalahti et al. (2002) included oats in the list of the allowed products. Pulido et al. (2009) reported that oats can be tolerated by most but not all people who are intolerant to gluten. The reason for this discussion is the close taxonomic relationship of oat species to wheat, rye and barley, which are harmful to people with coeliac disease (Kasarda, 2001). Oat has some wheat-like sequences in its protein structure, but these are less frequent in oats than in other prolamins. Nevertheless, there is no consensus among scientists and nutrition experts on whether oats can be unequivocally recommended for coeliac patients (Kaukinen et al., 2013).

Previous studies (Thompson et al., 2005; Saturni et al., 2010) indicated unbalanced intake of carbohydrates, proteins, and fat, as well as a limited intake of certain essential nutrients in a gluten-free diet. Gluten-free products are mainly starchy foods with divergences in fat, fibre and protein composition, due to the occasional protein enrichment (Segura and Rosell, 2011). In consequence, these products have very low contribution to recommended daily protein and fibre intake. Oat is considered an interesting alternative, as it contains healthy compounds (essential amino acids, unsaturated fatty acids, beta-glucans, polyphenols) (Andon and Anderson, 2008). A study by Storsrud et al. (2003) indicated that including oat in a gluten-free diet significantly $(p<0.05)$ increased daily energy intake from cereals, as well as made the diet more pleasant (better taste, the satiating effect, more variability, and regulation of bowel function) for the patients and thereby increased compliance to the treatment. Similar results and conclusions were reported also by Kaukinen et al. (2013) and Comino et al. (2013). Due to the high nutritional value of oat, it would be positive change if oat could be considered as a part of a gluten-free diet.

The rising attention globally given to the use of oats and oat compounds and their beneficial effect in nutrition has increased interest in oat production in Latvia. Many studies on husked and hulless oat breeding and their quality parameters have been carried out in Latvia in recent years (Zute et al., 2011; Nakurte et al., 2013; Bleidere et al., 2014; Zute et al., 2015).

Oat (Avena sativa L.) is one of the most important among the group of crops with high energy and nutritional value arising from a high content of proteins and lipids. Proteins have important effect on cereal grain nutritional quality for humans and livestock and on their functional properties in food processing (Shewry and Halford, 2002). Oats are also a good source of soluble fibre, essential amino acids, unsaturated fatty acids, vitamins, minerals and phytochemicals (Jones, 2003; Arendt and Zannini, 2013). The chemical composition of oat grain makes it a very useful component of the diet for humans and animals and a source for industrial products. Givens et al. (2004) reported that variety and also site and year factors had high effect on the chemical composition and nutritive value of oats, followed by nitrogen fertiliser treatment.
Oats generally can be divided into two categories: husked oats and hulless oats. Around the world hulless oats are most often used for fodder, however, the chemical content and nutritional value of hulless oats have stirred interest about their use in food products (Radaelli et al., 2009; Behall and Hallfrisch, 2011; Tiwari and Cummins, 2012). Compared with husked oat grain, hulless oat grain has a lower fibre and a higher energy value, and contains more protein and lipids (Givens et al., 2004; Biel et al., 2009).

The content of essential amino acids in protein of oats is high because the major storage protein is globulin (Biel et al., 2009; Klose and Arendt, 2012). According to Shewry and Halford (2002) globulins have a higher concentration of lysine and other essential amino acids than prolamins, which are typical cereal storage proteins. Amino acids are the key building blocks of proteins and other essential biomolecules and play important roles in chemical reactions vital to life (Armenta et al., 2010).

The aim of this study was to evaluate protein, amino acid and gluten content in husked and hulless oat grains grown in organic and conventional farming systems.

\section{MATERIALS AND METHODS}

Field trials were completed at the State Stende Cereal Breeding Institute (SSCBI). Chemical analyses were performed in laboratories of the Faculty of Food Technology, Latvia University of Agriculture, and in the Lithuanian University of Health Science. Two hulless oat (Avena sativa L.) genotypes (breeding line '33793' and variety 'Stendes Emilija') and one husked oat variety 'Lizete' from SSCBI were cultivated in 2013 under conventional and organic farming conditions. In total, twelve oat samples were analysed. The abbreviations of the samples used in the article are described in Table 1.

Field trials were carried out on sod-podzolic sandy loam soil. The content of soil organic substances at the study sites was 21-24 $\mathrm{g} \cdot \mathrm{kg}^{-1}$, soil $\mathrm{pH} \mathrm{KCl}$ was $5.3-5.8$, content of

Table 1

OAT SAMPLES INCLUDED IN THE STUDY

\begin{tabular}{|c|c|c|c|c|}
\hline Sample & $\begin{array}{c}\text { Variety or } \\
\text { breeding line }\end{array}$ & Seed & $\begin{array}{c}\text { Farming } \\
\text { system }\end{array}$ & $\begin{array}{c}\text { Fertiliser, } \\
\mathrm{kg} \cdot \mathrm{ha}^{-1}\end{array}$ \\
\hline L-CG-N80 & Lizete & husked & conventional & 80 \\
\hline L-CG-N120 & Lizete & husked & conventional & 120 \\
\hline L-CG-N160 & Lizete & husked & conventional & 160 \\
\hline L-OG-NO & Lizete & husked & organic & - \\
\hline 3-CG-N80 & 33793 & hulless & conventional & 80 \\
\hline 3-CG-N120 & 33793 & hulless & conventional & 120 \\
\hline 3-CG-N160 & 33793 & hulless & conventional & 160 \\
\hline 3-OG-NO & 33793 & hulless & organic & - \\
\hline S-CG-N80 & Stendes Emilija & hulless & conventional & 80 \\
\hline S-CG-N120 & Stendes Emilija & hulless & conventional & 120 \\
\hline S-CG-N160 & Stendes Emilija & hulless & conventional & 160 \\
\hline S-OG-N0 & Stendes Emilija & hulless & organic & - \\
\hline
\end{tabular}


plant-available phosphorus $\mathrm{P}_{2} \mathrm{O}_{5} 138-164 \mathrm{mg} \cdot \mathrm{kg}^{-1}$, and potassium $\mathrm{K}_{2} \mathrm{O} 175-211 \mathrm{mg} \cdot \mathrm{kg}^{-1}$. The field trials were carried out using three nitrogen $(\mathrm{N})$ application rates $(80,120$ and $160 \mathrm{~kg} \cdot \mathrm{ha}^{-1}$ ) in conventional growing conditions and in addition without fertiliser application under organic growing conditions. The common agronomic practices for organic management were used during the vegetation period. The treatments were laid out in a randomised complete block design; plot size was $10 \mathrm{~m}^{2}$ and four replicates were used.

Chemical analysis. In the studied samples protein and gluten content, as well as amino acid composition were determined. Protein content was determined as total nitrogen content by the Kjeldahl method. The content of protein was calculated using the nitrogen conversion coefficient 6.25 (ISO 5983-1:2005). Amino acid composition was analysed by high-performance liquid chromatography method according to the Waters AccQ Tag pre-column derivatisation procedure using the Waters AccQ Tag chemistry package at the Lithuanian University of Health Science.

Gluten content. Enzyme-linked immune sorbent assay (ELISA) was used as a Type 1 method of Codex Alimentarius for detection of gluten. Gluten content was measured using a Sandwich R5 ELISA (R-Biopharm AG, Darmstadt, Germany) test kit, which includes gliadin standards and all necessary reagents. RIDASCREEN@ Gliadin is a sandwich enzyme immunoassay for the quantitative analysis of contamination by prolamins from wheat (gliadin), rye (secalin), and barley (hordein) in raw products like flour (buckwheat, rice, corn, oats, teff) and spices as well as in processed food like noodles, ready-to-serve meals, bakery products, sausages, beverages and ice cream. The solid support of the reaction is a microtitre plate coated with monoclonal antibody R5 that recognises the potentially toxic QQPFP pentapeptide found in gliadin-fractions (Méndez et al., 2005). After preparation of $0.25 \mathrm{~g}$ of homogenized sample, $2.5 \mathrm{ml}$ of the Cocktail (patented) (R-Biopharm) were added and incubated for 40 minutes at $50 \pm 1{ }^{\circ} \mathrm{C}$ in a water bath FL08D (Clifton Food Range, UK), then mixed with $7.5 \mathrm{ml} 80 \%$ ethanol and stirred for $1 \mathrm{~h}$, and then centrifuged at $3000 \mathrm{rpm}$ for 10 minutes in a centrifuge Sky Line CM-6MT (Elmi, Latvia). The sample was diluted $1: 12.5$ and a $100 \mu \mathrm{L}$ were filled into the microplate wells. The wells of microtitre strips are coated with specific antibodies against gliadins. By adding the standard or sample solution to the wells, the present gliadin is bound to the specific capture antibodies. The result is an antibody-antigen-complex. Then $100 \mu \mathrm{L}$ antibody conjugated to peroxidase was added. This antibody-conjugate is bound to the antibody-antigen-complex and a complex (sandwich) is formed. Any unbound enzyme conjugate was then removed in a washing step. Enzyme substrate and chromogen $(50 \mu \mathrm{L}$ each) were added to the wells and incubated for 30 minutes at room temperature. Then, $100 \mu \mathrm{l}$ of the stop solution was added and absorbance was measured at $450 \mathrm{~nm}$ in a microplate reader (Assys Expert Plus, UK). Six different concentrations of gliadin standards were used for construction of a gliadin standard calibration curve (Fig. 1).

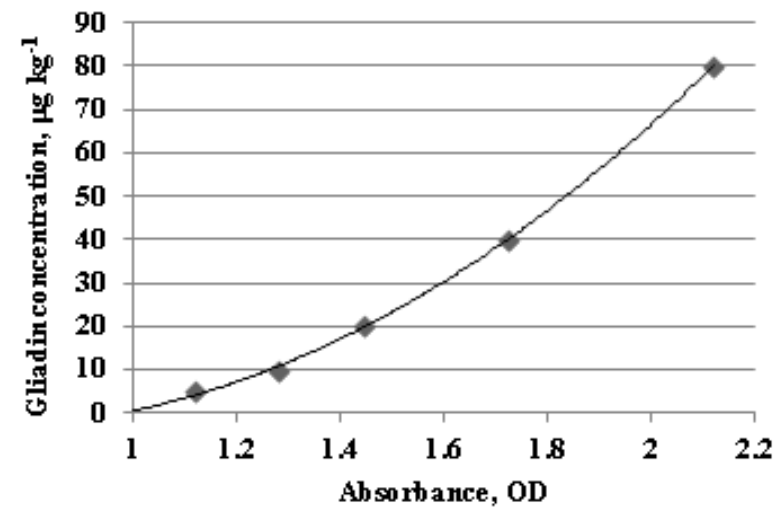

Fig. 1. Gliadin standard calibration curve.

Gliadin concentration (GL) was calculated using the equation (1) obtained from the calibration curve (Fig. 1), then multiplied by a dilution factor and a factor 2 in order to obtain the gluten concentration (GC) using equation (2).

$\mathrm{GL}=1.246 \mathrm{Abs}^{3}+35.251 \mathrm{Abs}^{2}-48.226$

$G C=\frac{G L \times 2000}{1000} \times 2$, where

GL - gliadin concentration, $\mu \mathrm{g} \mathrm{kg}{ }^{-1}$; Abs - absorbance at $450 \mathrm{~nm}, \mathrm{OD} ; \mathrm{GC}$ - gluten concentration, $\mathrm{mg} \cdot \mathrm{kg}^{-1} ; 2000$ dilution factor; 1000 and 2 - coefficients.

Statistical analysis. The results (mean, standard deviation, $p$ value) were processed by mathematical and statistical methods. Data were subjected to one-way and two-way analysis of variance (ANOVA), significance was defined at $p<0.05$; correlation analysis was done by Microsoft Office Excel 2007. Principal component analyses (PCA) was performed using MultiBase2015.

\section{RESULTS}

The protein content in oat samples is presented in Figure 2. The protein content in the analysed oat samples varied from $113.75 \pm 2.22 \mathrm{~g} \cdot \mathrm{kg}^{-1}$ (L-OG-N0) to $177.5 \pm 2.08 \mathrm{~g} \cdot \mathrm{kg}-1$ (S-CG-N160). The genotype had significant impact $(p<$ 0.001 ) on the protein content. The hulless oat samples (breeding line '33793' and variety 'Stendes Emilija') had a higher content of protein than in the husked oat samples. The protein content in oat samples grown in the conventional farming system was higher by about $7.47 \%$ (N80), $8.25 \%(\mathrm{~N} 120)$ and $10.89 \%(\mathrm{~N} 160)$ than in samples from the organic farming system. The applied amount of fertiliser did not have significant effect $(p=0.84)$, but the growing system had effect $(p<0.001)$ on the protein content.

Analysis of variance showed significant difference ( $p=$ 0.01 ) in the total amount of amino acids between husked and hulless oat genotypes (Fig. 3).

The highest content of amino acids was found in hulless oat breeding line 33973 (sample 3-CG-N120) grown in the conventional farming system $-132.44 \pm 0.09 \mathrm{~g} \cdot \mathrm{kg}^{-1}$, and the 

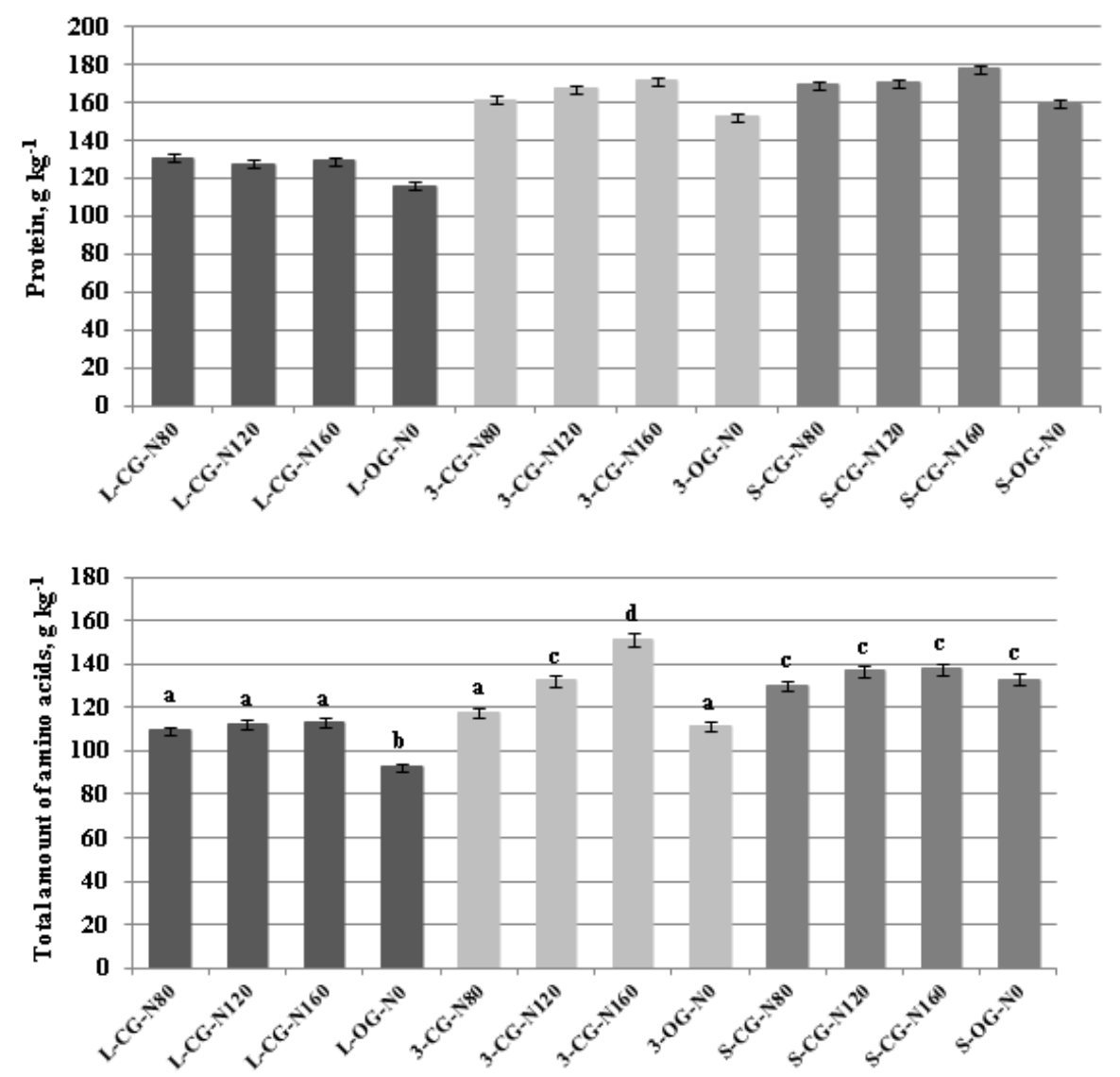

Fig. 2. Protein content in the oat samples.

Fig. 3. The total amino acid content in oat samples. $*$ The different letters represent significant differences between values $(p<0.05)$. lowest $\left(92.70 \pm 0.07 \mathrm{~g} \cdot \mathrm{kg}^{-1}\right)$ in husked oat variety 'Lizete' (sample L-OG-N0) grown in the organic farming system. The applied amount of fertiliser did not have significant $(p=0.08)$ effect on total amino acid content in oats. All four hulless oat samples of the variety 'Stendes Emilija' had similar content of total amino acids in the range $130.13 \pm$ $0.05 \mathrm{~g} \cdot \mathrm{kg}^{-1}$ to $137.87 \pm 0.04 \mathrm{~g} \cdot \mathrm{kg}^{-1}$. Applied amount of fertiliser also did not have a significant effect $(p>0.05)$ on the total amino acid content. Only hulless oat genotype '33793' showed obvious variation in the total amount of amino acids. A strong positive correlation was found between total protein content and total content of amino acids $(r=0.94$ for variety 'Lizete', $r=0.92$ for the breeding line '33793' and a medium strong positive correlation $r=0.57$ for the variety 'Stendes Emilija').

Oat samples were rich in essential amino acids (Table 2), such as leucine $\left(7.77-11.98 \mathrm{~g} \cdot \mathrm{kg}^{-1}\right)$, valine $(5.29-8.17$ $\left.\mathrm{g} \cdot \mathrm{kg}^{-1}\right)$ and phenylalanine $\left(4.64-7.80 \mathrm{~g} \cdot \mathrm{kg}^{-1}\right)$ and also in non-essential amino acids such as glutamic acid (19.73$\left.36.15 \mathrm{~g} \cdot \mathrm{kg}^{-1}\right)$, arginine $\left(7.82-12.21 \mathrm{~g} \cdot \mathrm{kg}^{-1}\right)$ and proline $\left(7.12-10.16 \mathrm{~g} \cdot \mathrm{kg}^{-1}\right)$.

In organically grown oats of the variety 'Lizete' and the breeding line '33793', content of total amino acids and essential amino acids was significantly lower $(p<0.05)$ compared to that in conventionally grown oats (Table 2). Amount of fertiliser (N120 and N160) applied to hulless oat variety 'Stendes Emilija' significantly affected $(p<0.05)$ the content of non-essential amino acids (lysine and phenyl- alanine), as well as of total essential amino acid content. Glutamic acid content in the oat samples was significantly positively affected by amount of applied fertilizer. In all studied oat genotypes the content of non-essential amino acid was higher than that of essential amino acids, which ranged from $33.57 \mathrm{~g} \cdot \mathrm{kg}^{-1}$ in the sample L-OG-N0 to $53.70 \mathrm{~g} \cdot \mathrm{kg}^{-1}$ in the sample S-CG-N160 (Table 1).

The content of gluten in oat samples grown in the organic farming system was higher by about $10.5 \%$ in variety 'Lizete', $15.2 \%$ in the breeding line '33793' and 3.5\% in the variety 'Stendes Emilija' (Fig. 4) compared to levels in conventionally grown oats.

Two-way analysis of variance showed that the used amount of fertiliser did not have significant effect $(p=0.18)$ on glu-

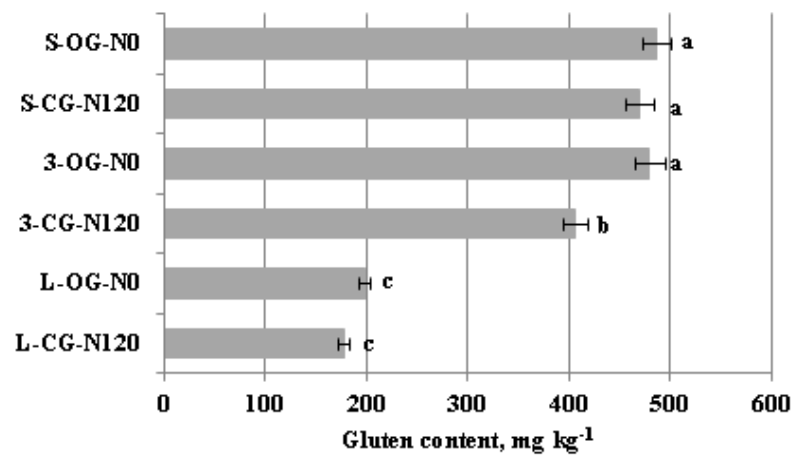

Fig. 4. Gluten content of oat samples. * The different letters represent significant differences between gluten content $(p<0.05)$. 
AMINO ACID COMPOSITION IN THE STUDIED OAT SAMPLES

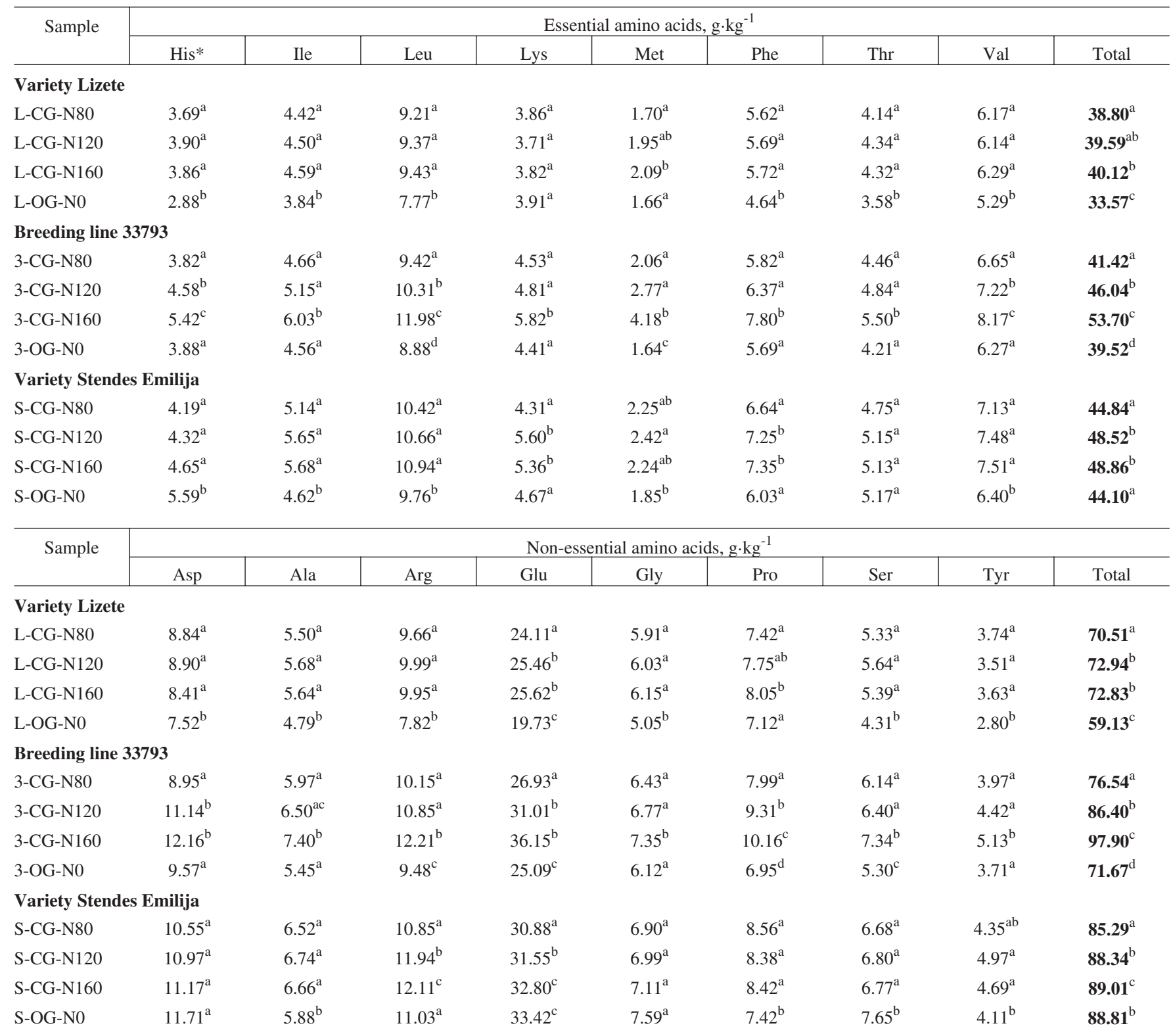

* His - histidine, Ile - isoleucine, Leu - leucine, Lys - lysine, Met - methionine, Phe - phenylalanine, Thr - threonine, Val - valine, Asp - aspartic acid, Ala - alanine, Arg - arginine, Glu - glutamic acid, Gly - glycine, Pro - proline, Ser - serine, Tyr - tyrosine

** Similar letters in the same column within genotypes and amino acid groups represent absence of significant differences between average values at $p=0.05$.

ten content in the studied oat samples, but oat genotype was a significant factor $p=0.01$. The gluten content in the analysed oat samples was in the range from $177.05 \pm 0.03$ $\mathrm{mg} \cdot \mathrm{kg}^{-1}$ (variety 'Lizete', sample L-CG-N120) to $486.57 \pm$ $0.05 \mathrm{mg} \cdot \mathrm{kg}^{-1}$ (variety 'Stendes Emilija', sample S-OG-N0). In hulless oat variety 'Stendes Emilija' and breeding line '33793' the content of gluten was higher than $400 \mathrm{mg} \cdot \mathrm{kg}^{-1}$, which was 4-5 times higher than the allowed level (100 $\mathrm{mg} \cdot \mathrm{kg}^{-1}$ ) for labelling as 'very low gluten' (EU Commission regulation No. 41/2009). Gluten content in the oat samples had a strong correlation $(r=0.88)$ with the total protein content. Principal component analysis (PCA) of protein, amino acids and gluten demonstrated that differences be- tween oat samples can be explained by three factors: the first two PCA axes accounted for $96.1 \%$ of the total variation (Fig. 5). The PCA ordination indicates that the contents of amino acids and protein were related, but gluten content - dissimilar and not related to protein and amino acid content, this is also confirmed by the correlation analysis. According to the PCA oat samples can be grouped in three groups based on similarity of physical-chemical properties.

\section{DISCUSSION}

The protein content in oat grains varies from $12 \%$ to even $20 \%$ depending on growing conditions and genotype (Riahi 


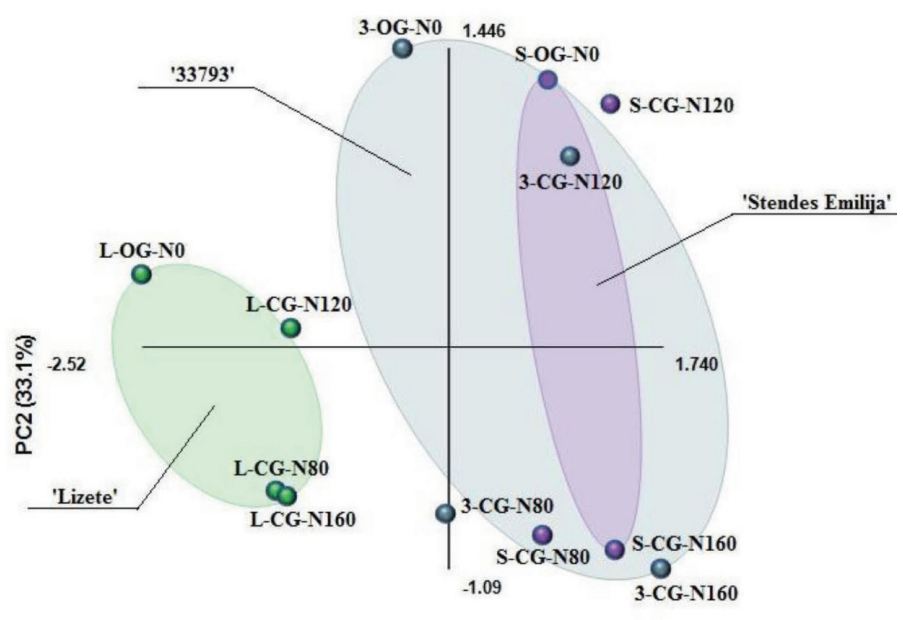

PC1 $(63 \%)$

Fig. 5. PCA of protein, amino acids and gluten content of oat samples.

and Ramaswamy, 2003; Arendt and Zannini, 2013). In this study, it was established that protein content in the husked oat samples $\left(113.75-127.8 \mathrm{~g} \cdot \mathrm{kg}^{-1}\right)$ was lower than that in the hulless oat genotype $\left(152.0-177.5 \mathrm{~g} \cdot \mathrm{kg}^{-1}\right)$. The protein content in husked and hulless oat in this study was higher than those (104.9 and $126.7 \mathrm{~g} \cdot \mathrm{kg}^{-1}$ ) reported by Biel et al. (2014), and 93.0 and $120.0 \mathrm{~g} \cdot \mathrm{kg}^{-1}$ reported by Givens et al. (2004). These observed differences with previous studies might be caused by specific traits of the selected genotypes, different agronomic and environmental conditions in the location where the studies were carried out. The protein content in oat grain mostly depends on agro-meteorological conditions: genotype, nitrogen treatment, sowing date and weather conditions (Givens et al., 2004).

The amino acid composition of oat affect the quality of proteins and their amino acid properties (Givens et al., 2004; Baker, 2007, Biel et al., 2009; Biel et al., 2014). Hulless oat contains more $(p \leq 0.05)$ lysine (Lys), threonine (Thr) and isoleucine (Ile) than husked oats. Total content of essential amino acids in the protein of hulless oats was by $12 \%$ higher than that in husked oats (Biel et al., 2014). This was also shown in our study; the total content of essential amino acids in the hulless oat breeding line '33793' and the variety 'Stendes Emilija' was higher by $15.8 \%$ and $18.4 \%$, respectively, compared to that in husked oat samples. Givens et al. (2004) also reported significant difference $(p<0.001)$ between amino acid content in hulless and husked oat. Husked oat cultivars have higher amino acid content than hulless oats. The studied oat samples were rich in non-essential amino acids such as glutamic acid (Glu), arginine (Arg) and proline (Pro) and essential amino acids such as leucine (Leu), valine (Val) and phenylalanine (Phe), as previously reported (Givens et al., 2004; Georgieva and Zorovski, 2013; Biel et al., 2014). Oats are characterised by higher essential amino acid content than in other cereals, because the major proteins of oats are globulins (Shewry and Halford, 2002).

The suitability of oats for people with coeliac disease is widely discussed (Dickey, 2008; Lester, 2008; Heap and van Heel, 2009; Pulido et al., 2009; Londono et al., 2013). Including oats in the gluten-free diet could be advantageous, since oats are a good source of dietary fibre and of several vitamins and minerals.

There was no significant difference $(p>0.05)$ between the effect of applied N120 and N160 fertiliser on protein and total amino acid content. Thus, the optimal amount of fertiliser is N120, considering quality parameters and expenses. Thus, samples from this treatment weree selected for the further studies of gluten content.

Gluten is the general name for prolamines found in wheat (gliadin), rye (secalin), barley (hordein) and oat (avenins) (Pietzak and Fasano, 2005). Protein composition of oats is different from cereals (wheat, barley and rye) that are considered harmful for people suffering from coeliac disease. Prolamines constitute the major fraction in wheat, barley and rye, but in oats salt-soluble globulines are more dominant. The prolamin fraction in oats is about $10 \%$ of the total protein content. Oat prolamins have monogenic nature and about $10 \%$ of their amino acid content consists of proline, which is about half of the amount that is found in prolamins of wheat, barley and rye (Kanerva et al., 2012). Wheat gliadin is unique in terms of amino acid composition, as it is characterised by high contents of glutamine and proline and by low contents of leucine and alanine. Specific peptide sequences especially rich in proline and glutamine (Pro-SerGln-Gln and Gln-Gln-Gln-Pro) produce autoimune enteropathy. Those peptides are found in wheat gliadin, rye secalins, barley hordeins, and, in much a lower amount, oat avenins (Guilbert et al., 2002; Wieser, 2004). Thus amino acid composition is essential in detecting suitability of cereals for a gluten-free diet.

Sandwich R5 ELISA was used for detection of gluten in oats. This method is based on detection of prolamins from wheat (gliadin), rye (secalin), and barley (hordein) in raw products like flours (buckwheat, rice, corn, oats, teff) and spices as well as in processed food like noodles, bakery products and beverages. The monoclonal antibody R5 does not recognise prolamins from soybean, oat, corn and rice (prolamins from gluten-free cereals differ from wheat, rye and barley by amount and structure), but recognises and binds certain amino acid sequences (glutamine-glutamineproline-phenylalanine-proline) from wheat, rye, and barley, which are considered as harmful. Previously, Ballabio et al. (2011) and Sharma et al. (2015) applied RIDASCREEN® Gliadin for gluten content determination in oats.

In the first stage of experiments, gluten content was evaluated in six oat samples (samples grown in a conventional farming system using nitrogen application rate $120 \mathrm{~kg} \cdot \mathrm{ha}^{-1}$ (sample N120) and samples grown in organic farming system). In all studied oat samples gluten content exceeded the allowed amount of $100 \mathrm{mg} \mathrm{kg}^{-1}$. The hulless oat breeding line '33793' and the variety 'Stendes Emilija' has similar amounts of gluten, while the husked oat variety 'Lizete' had two times lower gluten content. Hulless oat samples had a higher gluten content than in husked oat samples, and oat 
genotype significantly affected $(p<0.05)$ gluten content. Hernando et al. (2008) analysed gluten content in 109 oat samples (rolled oats, oat flakes, oatmeal, oat flour, oat brans, and oat grains) and found that $25 \%$ of oats had gluten content $<3 \mathrm{mg} \cdot \mathrm{kg}^{-1}, 4 \%$ had content between 3 and $20 \mathrm{mg} \cdot \mathrm{kg}^{-1}, 12 \%$ between 20 and $200 \mathrm{mg} \cdot \mathrm{kg}^{-1}$ and $59 \%$ exceeded the level of $200 \mathrm{mg} \cdot \mathrm{kg}^{-1}$. These observed differences with our results can be due to type of oat sample and previous treatment and processing. Gluten content in the husked oat variety 'Lizete' $177 \mathrm{mg} \cdot \mathrm{kg}^{-1}$ (L-CG-N120) and $198 \mathrm{mg} \cdot \mathrm{kg}^{-1}$ (L-OG-N0) was the closest to the allowed limit $\left(100 \mathrm{mg} \cdot \mathrm{kg}^{-1}\right)$. Proline and glutamine are reported as most toxic for people with coeliac disease (Guilbert et al., 2002; Wieser, 2004). Amino acids glutamine (Gln) and glutamic acid (Glu) are closely related in a chemical sense and both amino acids play an important role in the development of autoimmune reaction in coeliac disease (Sollid, 2000). Results of our study showed that husked oat variety 'Lizete' samples, which have lower gluten content, also have lower proline (Pro) (7.12-7.75 g. $\left.\mathrm{kg}^{-1}\right)$ and glutamic acid (19.73$\left.25.46 \mathrm{~g} \cdot \mathrm{kg}^{-1}\right)$ content than in the hulless oat variety 'Stendes Emilija' (Pro 7.42-8.38 g. $\mathrm{kg}^{-1}$, Glu 31.55-33.42 $\mathrm{g} \cdot \mathrm{kg}^{-1}$ ) and the breeding line '33793' (Pro 6.75-9.31 $\mathrm{g} \cdot \mathrm{kg}^{-1}$, Glu 25.09-31.01 $\left.\mathrm{g} \cdot \mathrm{kg}^{-1}\right)$. Guilbert with co-workers (2002) reported that wheat gliadin contains $14-17 \mathrm{~g} \cdot \mathrm{kg}-1$ proline, which is approximately two times higher than in our study. According to Wieser (2004), wheat gliadin contains $37 \mathrm{~g} \cdot \mathrm{kg}^{-1}$ glutamine, $17 \mathrm{~g} \cdot \mathrm{kg}^{-1}$ proline, $7 \mathrm{~g} \cdot \mathrm{kg}^{-1}$ leucine (Leu) and $3 \mathrm{~g} \cdot \mathrm{kg}^{-1}$ alanine (Ala). Our analysed oat samples contained a higher amount of leucine and alanine than gliadin. The samples of oat variety 'Lizete' had lower content of leucine $\left(7.77-9.37 \mathrm{~g} \cdot \mathrm{kg}^{-1}\right)$ and alanine (4.79-5.68 $\mathrm{g} \cdot \mathrm{kg}^{-1}$ ) than in the hulless oat variety 'Stendes Emilija' (Leu 9.76-10.66 $\mathrm{g} \cdot \mathrm{kg}^{-1}$, Ala 5.88-6.74 $\left.\mathrm{g} \cdot \mathrm{kg}^{-1}\right)$ and the breeding line '33793' (Leu 8.88-10.31 g. kg ${ }^{-1}$, Ala 5.45-6.50 g. $\mathrm{kg}^{-1}$ ). It is necessary in the next investigations to include other oat genotypes for determine their gluten content, in the search for those contain gluten within allowed limits.

\section{ACKNOWLEDGEMENTS}

This research was financed by the European Social Fund Project No. 1DP/1.1.1.2/13/APIA/VIAA/032.

\section{REFERENCES}

Andon, M., Anderson, J. (2008). The oatmeal-cholesterol connection: 10 years later. Amer. I. Lifestyle. Med., 2 (1), 51-57.

Anonymous (2009). EU Commission Regulation (EC) No 41/2009. Concerning the composition and labelling of foodstuffs suitable for people intolerant to gluten. January 20.

http://eurlex.europa.eu/LexUriServ/LexUriServ.do?uri=OJ:L:2009:016:0 003:0005:EN:PDF (accessed 10 April 2015).

Anonymous (2015). CODEX STAN 118 - 1981. Codex standard for foods for special dietary use for persons intolerant to gluten.

http://www.codexalimentarius.org/input/download/standards/291/ cxs_118e.pdf (accessed 10 April 2015).

Arendt, E. K., Nunes, M. H. B. (2010). Processing gluten-free foods. In: Boye, J. I., Godefroy, S. B. (eds.). Allergen Management in the Food Industry. John Wiley \& Sons, New Jersey, pp. 333-354.
Arendt, E. K., Zannini, E. (2013). Cereal Grains for the Food and Beverage Industries. Woodhead Publishing, Cambridge. 485 pp.

Armenta, J. M., Cortes, D. F., Pisciotta, J. M., Shuman, J. L., Blakeslee, K., Rasoloson, D., Ogunbiyi, O., Sullivan, D. J., Shulaev, V. (2010). A sensitive and rapid method for amino acids quantitation in malaria biological samples using AccQTag UPLC-ESI-MS/MS with multiple reaction monitoring. Anal. Chem., 82 (2), 548-558.

Baker, D. (2007). Lysine, arginine, and related amino acids: An introduction to the 6 thamino acid assessment workshop. J. Nutr., 137, 1599S-1601S

Ballabio, C., Uberti, F., Manferdelli, S., Vacca, E., Boggini G., Redaelli, R., Catassi, C., Lionetti, E., Penas, E., Restanti, P. (2011). Molecular characterisation of 36 oat varieties and in vitro assessment of their suitability for coeliac's diet. J. Cereal. Sci., 54, 110-115.

Behall, K. M., Hallfrisch, J. (2011). Oats as a functional food for health. In: Webster, F. H., Wood, P. J (eds.). Oats Chemistry and Technology. AACC International Press, pp. 257-267.

Biel, W., Bobko, K., Maciorowski, R., (2009). Chemical composition and nutritive value of husked and naked oats grain. J. Cereal. Sci., 49, 413-418.

Biel, W., Jacyno, E., Kawecka, M. (2014). Chemical composition of hulled, dehulled and naked oat grains. South African J. Animal Sci., 44 (2), 189-197.

Bleidere, M., Timbare, R., Bobere N., Paklone, M., Jākobsone, I., Zute, S. (2014). Characterisation of hulled oat grain physical and biochemical parameters significant for dietary products. Proc. Latv. Acad. Sci., Section B, $68(3 / 4), 166-173$.

Comino, I., de Lourdes Moreno, M., Real, A., Rodriguez-Herrera, A., Barro, F., Sousa, C. (2013). The gluten-free diet: Testing alternative cereals tolerated by coeliac patients. Nutrients, $\mathbf{5}, 4250-4268$.

Di Sabatino, A., Corazza, G. R. (2009). Coeliac disease. Lancet, 373, 1480-1493.

Dickey, W. (2008). Making oats safer for patients with coeliac disease. Eur. J. Gastroenterol. Hepatol., 20, 494-495.

Georgieva, T., Zorovski, P. (2013). The content of non-essential amino acids in the grains of winter and spring varieties of oats (Avena sativa L.) under the conditions of Central Southern Bulgaria. Agro-knowledge J., 14 (1), 105-113.

Givens, D. I., Davies, T. W., Laverick, R. M. (2004). Effect of variety, nitrogen fertilizer and various agronomic factors on the nutritional value of husked and naked oats grain. Anim. Feed Sci. Tech., 113, 169-181.

Guilbert, S., Gontard, N., Morel, M. H., Chalier, P., Micard, V., Redl, A. (2002). Formation and properties of wheat gluten films and coating. In: Gennadios, A. (Ed.). Protein-Based Films and Coastings. CRC Press, Boco Raton, pp. 69-122.

Heap, G. A., van Heel, D. A. (2009). Genetics and pathogenetics of coelic disease. Semin. Immunol., 21, 346-354.

Hernando, A., Mujico, J. R., Mena, M. C., Lombardia, M. M., Mendez, E. (2008). Measurement of wheat gluten and barley hordeins in contaminated oats from Europe, the United States and Canada by Sandwich R5 ELISA. Eur. J. Gastroenterol. Hepatol., 20 (6), 545-554.

Jones, J. B. (2003). Chapter 2. Grain crops. In: Agronomic Handbook Management of Crops, Soils and Their Fertility. CRC Press, Boca Raton, London, New York, Washington, D.C., pp. 17-125.

Kanerva, P., Brinck, O., Salovaara, H., Sontag-Strohm, T. (2012). Analysis of oat and buckwheat proteins by sandwich R5 ELISA. In: Proceeding of the 25th Meeting Working Group on Prolamin Analysis and Toxicity, 29 September - 2 October 2011 Verlag Deutsche Forschungsanstalt fur Lebensmittelchemie, Fellbach, Germany, pp. 43-46.

Kasarda, D. D. (2001). Grains in relation to celiac disease. Cereal Foods World, 46, 209-210.

Kaukinen, K., Collin, P., Huhtala, H., Maki, M. (2013). Long-term consumption of oats in adult celiac disease patients. Nutrients, 5, 4380-4389.

Klose, C., Arendt, E. K. (2012). Proteins in oats; their synthesis and changes during germination: A review. Crit. Rev. Food Sci. Nutr., 52 (7), 629-639. 
Lester, D. R. (2008). Gluten measurement and its relationship to food toxicity for celiac disease patients. Plant Methods, 4 (26), 1-5.

Londono, D. M., van't Westende, W. P. C., Goryunova, S., Salentjin, E. M. J., van den Broeck, H. C., van der Meer, I. M., Visser, R. G. F., Gilissen, L. J. W. J., Smulders, M. J. M. (2013). Avenin diversity analysis of the genus Avena (oat). Relevance for people with celiac disease. J. Cereal Sci., 58, 170-177.

Méndez, E., Vela, C., Immer, U., Janssen, F. W. (2005). Report of a collaborative trial to investigate the performance of the R5 enzyme linked immunoassay to determine gliadin in gluten-free food. Eur. J. Gastroenterol. Hepatol., 17, 1053-1063.

Mustalahti, K., Lohiniemi, S., Collin, P., Vuolteenaho, N., Laippala, P., Maki, M. (2002). Gluten-free diet and quality of life in patients with screen-detected celiac disease. Eff. Clin. Pract., 5 (3), 105-113.

Nakurte, I., Kirhnere, I., Namniece, J., Saleniece, K., Krigere, L., Mekss, P., Vicupe, Z., Bleidere, M., Legzdina L., Muceniece, R. (2013). Detection of the lunasin peptide in oats (Avena sativa L). J. Cereal. Sci., 57.(3), 319-324.

Niewinski, M. M. (2008). Advances in celiac disease and gluten-free diet. $J$. Amer. Diet. Assoc., 108 (4), 661-672.

Pietzak, M. M., Fasano, A. (2005). Celiac disease: A new paradigm of an immune-mediated disorder due to dietary gluten. In: Preedy, V. R., Watson, R. R. (eds.). Review in Food and Nutrition Toxicity, Vol. 3. CRS Press, Boca Raton, Florida, pp. 243-266.

Pulido, M. O., Gillespie, Z., Zarkadas, M., Dubois, S., Vavasour, E., Rashid, M., Switzer, C., Godefroy, S. B. (2009). Introduction of oats in the diet of individuals with celiac disease: A systematic review. Adv. Food Nutr. Res., 57, 235-285.

Redaelli, R., Sgrulletta, D., Scalfati, G., De Stefanis, E., Cacciatori, P. (2009). Naked oats for improving human nutrition: Genetic and agronomic variability of grain bioactive components. Crop. Sci., 49 (4), 1431-1437.

Riahi, E., Ramaswamy, H. S. (2003). Structure and composition of cereal grains and legumes. In: Chakraverty, A., Mujumdar, A. S. Raghavan, G. S. V., Ramaswamy, H. S. (eds.). Handbook of Postharvest Technology Ce- reals, Fruits, Vegetables, Tea, and Spices. Marcel Dekker, New York, Basel, pp. 1-16.

Saturni, L., Ferretti, G., Bacchetti, T. (2010). The gluten-free diet: Safety and nutritional quality. Nutrients, 2, 16-34.

Segura, M. E., Rosell, C. M. (2011). Chemical composition and starch digestibility of gluten-free breads. Plant Food Hum. Nutr., 66 (3), 224-230.

Sharma, G. M., Pereira, M., Williams K. M. (2015). Gluten detection in foods available in the United States - A market survey. Food Chem., 169, 120-126.

Shewry, P. R., Halford, N. G. (2002). Cereal seed storage proteins: Structures, properties and role in grain utilization. J. Exp. Bot., 53 (370), 947-958.

Sollid, L. M. (2000). Molecular Basis of Celiac Disease. Annu. Rev. Immunol., 18, 53-81.

Storsrud, S., Hulthen, L. R., Lenner, R. A. (2003). Beneficial effects of oats in the gluten-free diet of adults with special reference to nutrient status, symptoms and subjective experiences. Brit. J. Nutr., 90, 101-107.

Thompson, T., Dennis, M., Higgins, L. A., Lee, A. R., Sharrett, M. K. (2005). Gluten-free diet survey: Are Americans with coelic disease consuming recommended amount of fiber, iron, calcium and grain foods? J. Hum. Nutr. Diet., 18, 163-169.

Tiwari, U., Cummins, E. (2012). Dietary exposure assessment of $\beta$-glucan in a barley and oat based bread. LWT-Food Sci. Technol., 47 (2), 413-420.

Torbica, A., Hadnadev, M., Dapčevic, T. (2010). Rheological, textural and sensory properties of gluten-free bread formulations based on rice and buckwheat flour. Food Hydrocolloid, 24, 626-632.

Wieser, H. (2004). Celiac Disease. In: Wrigley, C., Corke, H., Walker C. E. (eds.). Encyclopedia of Grain Science. Elsevier Academic Press, San Diego, pp. 179-187.

Zute, S., Berga, L., Vīcupe, Z., (2011). Variability in endosperm $\beta$-glucan content of husked and naked oat genotypes. Acta Biol. Univ. Daugavp., 11 (2), 192-200.

Zute, S., Brunava, L., Jansone, I., Tamm, Y. (2015). Influence of farming systems, nitrogen rates and meteorological conditions on naked oat in Latvia. Agr. For., 61 (1), 15-25.

Received 11 June 2015

\section{OLBALTUMVIELU, AMINOSKĀBJU UN GLUTĒNA SATURS LATVIJĀ AUDZĒTĀS AUZĀS (Avena sativa L.)}

Pasaulē un Latvijā pieaug interese par auzu izmantošanu uzturā un tajās esošo bioloǵiski aktīvo savienojumu pozitīvo ietekmi. Pētījumā izmantotas Valsts Stendes graudaugu selekcijas institūtā 2013. gadā konvencionālā lauka apstāklos ar trīs slāpekḷa (N) mēslojuma variantiem $\left(80,120\right.$ un $\left.160 \mathrm{~kg} \cdot \mathrm{ha}^{-1}\right)$ un bioloǵiskās audzēšanas apstākḷos bez $\mathrm{N}$ mēslojuma pielietojuma audzēti divi kailgraudu auzu (Avena sativa L.) paraugi — selekcijas līnija '33793' un šḳirne 'Stendes Emilija' un viena plēkšṇaino auzu šḳirne 'Lizete'. Pētījuma mērkis bija novērtēt olbaltumvielu, aminoskābju un glutēna saturu biolog̣iski un konvencionāli audzētās kailgraudu auzās un plēkšnainās auzās. Olbaltumvielu daudzums auzu paraugos tika noteikts ar Kjeldāla metodi, aminoskābju sastāvs ar škidruma hromatogrāfijas metodi izmantojot Waters AccQ Tag, glutēna saturs ar Sandwich R5 ELISA. Auzu genotipam ir būtiska ietekme $(p<0.001)$ uz olbaltumvielu un glutēna saturu, kā arī uz aminoskābju sastāvu. Lietotais mēslojuma daudzums būtiski neietekmē, bet audzēšanas apstākḷi būtiski ietekmē $(p<0.001)$ pētāmo kvalitātes parametru saturu. Kailgraudu auzu paraugos ir augstāks olbaltumvielu saturs, salīdzinot ar plēkšnainām auzām, kā arī pastāv būtiska atškirīiba $p=0.01$ starp šo paraugu kopējo aminoskābju saturu. Kailgraudu šķirnes 'Stendes Emilija' un selekcijas līnijas '33793' auzās ir līdzīgs glutēna saturs, kas ir divas reizes lielāks nekā plēkšņaino auzu škirnes 'Lizete' auzās. 